\begin{tabular}{|c|c|c|}
\hline & Int.J.Curr.Microbiol.App.Sci (2016) 5(7): $61-70$ & \multirow{2}{*}{ 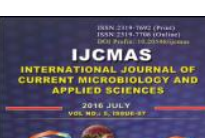 } \\
\hline & \multirow{4}{*}{$\begin{array}{l}\text { International Journal of Current Microbiology and Applied Sciences } \\
\text { ISSN: 2319-7706 Volume } 5 \text { Number } 7 \text { (2016) pp. } 61-70 \\
\text { Journal homepage: } \underline{\text { http://www.ijcmas.com }}\end{array}$} & \\
\hline & & \\
\hline EXCELLENT & & \\
\hline PUBLISHERS & & Mww: ijomas \\
\hline
\end{tabular}

Original Research Article

http://dx.doi.org/10.20546/ijcmas.2016.507.005

\title{
Studies on Cytotoxic Effects of Ochratoxin A Extracts on Human Cell Lines (Hfl-1 and Hep-2)
}

\author{
Jamal I. Elzwai ${ }^{1}$, Mohamed A. Ahmed ${ }^{1}$, Kofi A. Aidoo', \\ Allan A. Candlish ${ }^{2}$ and Alyaa M. Homoud ${ }^{3 *}$ \\ ${ }^{1}$ Food Technology Department, Faculty of Engineering and Technology, Sebha University \\ ${ }^{2}$ Biological and Biomedical Dept. School of life Sciences, Glaasgow Caledonian University, \\ Glasgow, UK \\ ${ }^{3}$ Home Economic Department (Nutrition), Faculty of science and art, Al Baha University, KSA \\ *Corresponding author
}

Keywords

Ochratoxin A

Aspergillus

carbonarius,

Aspergillus

ochraceus,

Penicillium

verrucosum.

Article Info

Accepted:

07 June 2016

Available Online:

10 July 2016
A B S T R A C T

Ochratoxin A (OTA), the mycotoxin produced by species of Aspergilli, specifically Aspergillus carbonarius and Aspergillus ochraceus, and Penicillium verrucosum have harmful effects on humans, animals, and crops that result in illnesses and economic losses. Therefore, this study has been undertaken the cytotoxic effects of ochratoxin A of the four moulds extracts which has been used in this study in two human cell lines(Hfl-1 and Hep-2). Control experiment (uncontaminated solid substrate extract) showed negligible cytotoxic effects on both cell lines after $72 \mathrm{hr}$ exposure. All mould (OTA) extracts examined showed a cytotoxic effect on both cell lines, although it is possible that other compounds in the extracts may have contributed to the cytotoxic effects. Effect of the toxin extracts on the cell lines increased with incubation time. Aspergillus ochraceus $\mathrm{J} 002$ and A. ochraceus strain CBS 588.68 showed higher cytotoxic effects on Hfl-1 than A. carbonarius J001 and $P$. verrucosum strain IMI 285522 whereas on Hep-2, A. carbonarius J001 and A. ochraceus strain CBS 588.68 showed higher cytotoxic effects than A. ochraceus J002 and $P$. verrucosum IMI 285522. IC $_{50}$ ranged between 1.37 to 38.87 using Hfl1 cells and 1.94 to 50.0 using Hep-2 cells. IC $_{50}$ values by Aspergillus ochraceus strain CBS 588.68 was not determined after $72 \mathrm{hr}$, this may have been due to higher concentration of OTA in the extract than suspected.

\section{Introduction}

Contamination of foodstuff with mycotoxins such as ochratoxins is a major matter of concern for human and animal health. Ochratoxin A (OTA) is a nephrotoxic and carcinogenic mycotoxin mainly produced by Penicillium verrucosum in temperate and cold climates and by Aspergillus ochraceus and related species belonging to section Circumdati in warmer and tropical climates. Aspergillus carbonarius and some species belonging to Aspergillus niger aggregate have been reported as OTA producers (Dalcero et al., 2002; Magnoli et al., 2003; Battilani et al., 2003; Abarca et al., 2004; Samson et al., 2004). Ochratoxin A has been 
detected worldwide in a wide range of food products, including cereals (Magnoli et al., 2006a), poultry feeds (Rosa et al., 2006), feedstuffs (Magnoli et al., 2005), green coffee beans (Pardo et al., 2004), dried vine fruits (Magnoli et al., 2004), peanuts (Magnoli et al., 2006b). Ochratoxin A is the major compound and the most toxic form, followed by ochratoxin B (OTB), which defers from OTA only by the substitution of chlorine by hydrogen in the isocoumarin moiety. Ochratoxin A is a structural analogue of phenylalanine, and contains chlorinated dihydroisocoumarine moiety. It inhibits protein synthesis (Creppy et al., 1983), and impairs blood coagulation (Gupta et al., 1979), glucose metabolism (Pitout, 1986), and induces oxidative damage by enhancing lipid peroxidation (Omar et al., 1991).

Ochratoxin A is strongly cytotoxic, inducing tubule - interstitial nephropathy in rats and in other animal species (Boorman, 1989; Krogh et al., 1988). Ochratoxin A dependent induction of apoptosis is reported in vivo (kidney of rats and mice) and in vitro (Gekle et al., 2000; Luhe et al., 2003). Presistant cell proliferation has also been described in the kidney as a consequence of cell death. Both carcinogenicity and cytotoxicity of OTA have been discussed in relation to free radical formation leading to oxidative cell damage (Schaaf, 2002).

The cytotoxicity of ochratoxin A has been investigated by several authors (Bondy and Armstrong, 1998; Dietrich et al., 2001). The carcinogenicity of OTA in rats and mice is well established, OTA induces renal tumours in rats of both sexes and in male mice (Bendele et al., 1985; Boorman, 1989). In rats, male animals have been found to be considerably more sensitive than females. In the rat kidney, tumour induction is seen at a dose level $(70 \mu \mathrm{g} / \mathrm{kg}$ body weight (Boorman, 1989).
The objective of this study was to investigate the cytotoxic effects of ochratoxin A extracted from 4 ochratoxigenic moulds in vitro using two human cell lines, Hfl-1 and Hep-2.

\section{Materials and Methods}

\section{Ochratoxigenic moulds and ochratoxin A preparation}

Fungal genera used in this experiment were Aspergillus ochraceus strain CBS 588.68 (CBS Holland) and Penicillium verrucosum strain IMI 285522 (CABI, UK), andtwo fungal species were isolated from cereal samples obtained from the south of Libya and named according to their morphological appearance according to Samson et al., 2002 as Aspergillus carbonariusisolate and $A$. ochraceusisolate. All fungal strains were grown on solid substrate at $25^{\circ} \mathrm{C}$ for 7 days. After incubation, OTA was extracted with methanol for $30 \mathrm{~min}$. Extracts were filtered using Whatman filter paper NO. 1 and the filtrates were evaporated under a stream of nitrogen. The residues (crude OTA extract) stored at $4^{\circ} \mathrm{C}$ until needed.

\section{Chemicals}

Ochratoxin A standard solution (RBiopharm, Rhone Ltd, Glasgow, Scotland). Dimethyl sulfoxide (DMSO) and 3-(4,5dimethylthiazol-2-yl) and 2,5diphenyltetrazolium bromide (MTT) (Sigma, Poole, UK) were used for cytotoxicity assay. The MTT method is based on the respiratory activity of the cell principally mitochondrial succinatetetrazolium reductase system, which converts the yellow tetrazolium salt to a blue formazan dye. The amount of formazan produced is proportional to the amount of living cells in the culture. Sterile phosphate buffer saline (PBS) (Cambrex Bio Science, 
Wokingham, UK) was used for cell lines washing.

\section{Cell Lines maintenance and OTA Extract application}

HeLa- derived larynx epithelium (Hep-2) cell line and Human foetal lung fibroblasts (Hfl-1) cell line were purchased from the European Collection of Cell Culture (ECCC, Salisbury, UK). The Hep-2 cell line was grown and maintained in minimal essential medium (MEM) (BioWhittaker, Berkshire, UK) containing Earls's salts and glutamine, whereas Hfl-1 cell lines fibroblasts was cultured and grown in Ham's F12 medium (BioWhittaker, Berkshire, UK). Both media were supplemented with $1 \% \quad(\mathrm{v} / \mathrm{v})$ nonessential amino acids (Bio Whittaker BE1-114E), $100 \mathrm{IU} \mathrm{ml}^{-1}$ penicillin (Sigma, $\mathrm{P}-0906), 100 \mu \mathrm{g} \mathrm{ml}^{-1}$ streptomycin, (Sigma, P- 0906), Amphotericin B $(0.25 \mu \mathrm{g} / \mathrm{ml}$, Bio Whittaker BE17-836E) and foetal bovine serum (FBS, 10\%, Bio Whittaker) at the attainment of $80-90 \%$ confluence determined by microscopy (Olympus CK2), $4 \mathrm{ml}$ Trypsin/EDTA solution (0.05\%-0.02\%, v/v) (Gibco, Paisley, UK) was added for cell detachment, and the cells washed twice with sterile PBS (Sigma, UK) to ensure trypsin/EDTA removal. It was then transferred into a fresh media and incubated at $37^{\circ} \mathrm{C}, 5 \% \mathrm{CO}_{2}$ incubator until needed.

Five milliliter of fresh medium were used to reconstitute OTA and a serial dilution was made in triplicate using $100 \mu \mathrm{l}$ of toxin extracts in 96 microtiter plates (TPP, Trasadingen, Switzerland). One hundred microlitres $(100 \mu \mathrm{l})$ of cell suspension was added into each well and the background was made by distributing $200 \mu$ l of growth medium into 2 rows of eight wells and a negative toxin was made by distributing $100 \mu \mathrm{l}$ of the cell line. The plates were then incubated in a $\mathrm{CO}_{2}$ incubator $\left(5 \% \mathrm{CO}_{2}\right)$ at $37^{\circ} \mathrm{C}$ for 24,48 and $72 \mathrm{hr}$. Cell suspension was made as described by Finlay et al., (1999).

\section{Evaluation of Cytotoxicity of Fungal extracts}

An evaluation of the cytotoxicity of ochratoxin A extract was carried out using (MTT) assay. The procedure described by Betancur-Galvis et al., (1999) was employed in this experiment. After incubation of the cell lines with the OTA extracts, the supernatants were removed and $80 \mu 1$ of 3(4,5-dimethylthizole-2-yl)-2,5-

diphenyltetrazolium bromide was added to each well and incubated in $\mathrm{CO}_{2}$ incubator $\left(5 \% \mathrm{CO}_{2}\right)$ at $37^{\circ} \mathrm{C}$ for 4 hours, the dye was removed and then $100 \mu \mathrm{l}$ of Dimethylsulfoxide (DMSO) was added to dissolve any intracellular formazan crystal and followed by agitation for 15 minutes on a rotary shaker. Absorbance was measured in a plate reader (Dynex MRII, Worthing, UK) at $570 \mathrm{~nm}$. Absorbance of untreated cells served as control and background absorbance from wells containing no cells as a blank. The percentage of cytotoxicity was calculated using the formula,

$\%$ cell survival $=\frac{A-B}{A} \times 100$

Where, $A$ is the mean optical density of control wells, and $B$ is the optical density of wells with moulds extract.

$I C_{50}$ concentration was calculated from the linear Interpolation of the 2 test points that bracket $50 \%$ inhibition, one point lower and one point higher (MCL-5 Metabo, Woburn Massachusetts 2005) using the formula,

$$
I C_{50}=\frac{(50 \%-\text { low } \%) \times\left(C_{h}-C_{1}\right)}{\text { High } \%-\text { Low } \%}+C_{l}
$$


Where, $C_{h}=$ High concentration, $C_{l}=$ low concentration, High\%= High percentage, Low\% $\%$ low percentage.

The $I C_{50}$ value stands for a $50 \%$ inhibition of cell growth or metabolic cell activity.

\section{Results and Discussion}

Four ochratoxigenic moulds were grown on solid substrate at $25^{\circ} \mathrm{C}$ for 7 days. After incubation, OTA was extracted with methanol and the toxin extract of each mould was examined for their cytotoxicity effects on 2 human cell lines (Hfl-1 and Hep-2). $\mathrm{IC}_{50}$ values (concentration of toxin extract which result in $50 \%$ cell death) of each extract were determined on both cell lines. Tables 1 and table 2 showed the $\mathrm{IC}_{50}$ values obtained for each mould extract at different incubation time. Ochratoxin A extracted from Aspergillus carbonarius isolate showed a cytotoxic effect on both cell lines during the period of incubation (Table 3). The cytotoxicity of OTA extracted from A. carbonarius isolate was high on Hep-2 compared to that on Hfl-1, and resulted in $98 \%$ cell death after $24 \mathrm{~h}$, 99\% cell death after $48 \mathrm{~h}$, and $99 \%$ cell death after $72 \mathrm{~h}$ when $100 \mu \mathrm{l}$ of the OTA extract was added (OTA concentration was180 ppb). On Hfl-1, the percentage cell death at the same toxin concentration was $83 \%$ after $24 \mathrm{~h}, 91 \%$ after $48 \mathrm{~h}$ and $95 \%$ after $72 \mathrm{~h}$.

The toxic effect of OTA extracted from A. ochraceus isolate was determined during $72 \mathrm{~h}$ of incubation. Table 4 show the percentage cell death of both cell lines when $40 \mathrm{ppb}$ of the toxin extract was used. On Hep-2, the percentage cell death obtained after $24 \mathrm{~h}$ was $97 \%$, whereas $98 \%$ cell death was achieved after $48 \mathrm{~h}$ and $99 \%$ of cells death was achieved after $72 \mathrm{~h}$. For Hfl-1 cell lines, the percentage of cell death was $84 \%$ obtained after $24 \mathrm{~h}$, and $87 \%$ after $48 \mathrm{~h}$ and it was $97 \%$ after $72 \mathrm{~h}$. Aspergillus ochraceus strain CBS 588.68 showed cytotoxic effects on both cell lines (Table 5). The average percentage of cell death on Hep-2 cell lines with toxin extract concentration of 60ppb was $97 \%$ after $24 \mathrm{~h}$, whereas the percentage of cell death was $98 \%$ after $48 \mathrm{~h}$, and $99 \%$ after $72 \mathrm{~h}$. On Hfl-1 cell lines; $74 \%$ of the cell death was obtained after $24 \mathrm{~h}$ and $92 \%$ was obtained after $48 \mathrm{~h}$; and $98 \%$ of cell death was exhibited after $72 \mathrm{~h}$.

The cytotoxicity of OTA produced by Penicillium verrucosum strain IMI 285522 was determined in both cell lines. Table 6 show the cytotoxic effect of OTA extract on Hep-2 and on Hfl-1 cell lines. The percentage of cell death on Hep-2 obtained when a toxin concentration of 50ppb was added were $96 \%, 97 \%$ and $99 \%$ after $24 \mathrm{~h}$, $48 \mathrm{~h}$ and $72 \mathrm{~h}$ respectively, whereas on Hfl-1 cell line, the percentage of cell death was $87 \%$ after $24 \mathrm{~h}, 95 \%$ after $48 \mathrm{~h}$ and $99 \%$ after $72 \mathrm{~h}$.

The crude toxin extracts showed cytotoxic effects on both Hep-2 and Hfl-1; the effects increased with incubation time for both cell lines. Aspergillus ochraceus isolate and A. ochraceus strain CBS 588.68 showed higher cytotoxic effects on Hfl-1 than the other moulds, whereas on Hep-2 A. carbonarius isolate and A. ochraceus CBS588.68 showed higher cytotoxic effects than $A$. ochraceus isolate and $P$. verrucosum strain IMI 285522

The cytotoxicity of ochratoxin A has been investigated by several authors (Bondy and Armstrong, 1998; Dietrich et al., 2001). The carcinogenicity of OTA in rats and mice is well established, OTA induces renal tumours in rats of both sexes and in male mice (Bendele et al., 1985; Boorman, 1989). In rats, male animals have been found to be considerably more sensitive than females. 
Table.1 Mould extract concentration needed to obtain 50\% inhibition of Hfl-cell lines metabolism

\begin{tabular}{|c|c|c|c|}
\hline \multirow{3}{*}{ Fungi } & \multicolumn{3}{|c|}{ Incubation time (hr) } \\
\hline & 24 & 48 & 72 \\
\hline & \multicolumn{3}{|c|}{ Concentration $(\mu \mathrm{l} / \mathrm{ml})$} \\
\hline A. carbonariusisolate & 11.98 & 9.17 & 1.40 \\
\hline A. ochraceusisolate & 17.59 & 4.05 & 6.23 \\
\hline A. ochraceus CBS 588.68 & 24.10 & 11.83 & ND \\
\hline P. verrucosum IMI 285522 & 50.0 & 13.31 & 1.94 \\
\hline Negative control & ND & ND & ND \\
\hline
\end{tabular}

$\mathrm{ND}=$ not detected.

Table.2 Mould extract concentration needed to obtain $50 \%$ inhibition of Hep-2 cell lines metabolism

\begin{tabular}{|c|c|c|c|}
\hline \multirow{3}{*}{ Fungi } & \multicolumn{3}{|c|}{ Incubation Time (hr) } \\
\hline & 24 & 48 & 72 \\
\hline & \multicolumn{3}{|c|}{ Concentration $(\mu \mathrm{l} / \mathrm{ml})$} \\
\hline A. carbonariusisolate & 12.46 & 9.17 & 1.37 \\
\hline A. ochraceusisolate & 17.59 & 8.11 & 6.23 \\
\hline A. ochraceus CBS 588.68 & 17.50 & 11.83 & ND \\
\hline P. verrucosumIMI 285522 & 38.87 & 13.31 & 1.69 \\
\hline negative control & ND & ND & ND \\
\hline
\end{tabular}

$\mathrm{ND}=$ not detected.

Table.3 The cytotoxic effect of OTA (180ppb) extract produced by an A. carbonarius isolate on Hep-2 and Hfl-1 cell lines at different incubation periods

\begin{tabular}{|c|c|c|c|c|c|c|}
\hline \multirow{2}{*}{$\begin{array}{c}\text { OTA } \\
\text { concentration } \\
(\mathrm{ppb})\end{array}$} & \multicolumn{6}{|c|}{ Incubation time (hr) } \\
\cline { 2 - 7 } & \multicolumn{2}{|c|}{24} & \multicolumn{2}{c|}{48} & \multicolumn{2}{c|}{72} \\
\cline { 2 - 7 } & Hep-2 & Hfl-1 & Hep-2 & Hfl-1 & Hep-2 & Hfl-1 \\
\hline 180 & 98.15 & 82.89 & 99.18 & 91.34 & 99.91 & 95.26 \\
\hline 90 & 88.35 & 81.57 & 98.50 & 88.45 & 98.74 & 89.05 \\
\hline 45 & 83.01 & 68.42 & 86.50 & 78.87 & 98.50 & 84.91 \\
\hline 22.5 & 51.56 & 54.60 & 59.37 & 70.44 & 61.77 & 78.69 \\
\hline 11.25 & 32.67 & 33.55 & 41.74 & 58.80 & 54.09 & 71.00 \\
\hline 6.63 & 20.59 & 18.42 & 35.97 & 48.20 & 52.23 & 64.79 \\
\hline 3.31 & 15.19 & 15.13 & 31.89 & 36.28 & 51.63 & 52.36 \\
\hline 1.65 & 05.39 & 9.80 & 25.40 & 24.17 & 46.41 & 64.44 \\
\hline
\end{tabular}


Table.4 The cytotoxic effect of OTA (40ppb) extract produced by an A. ochraceus isolate on Hep-2 and Hfl-1 cell lines at different incubation periods.

\begin{tabular}{|c|c|c|c|c|c|c|}
\hline \multirow{2}{*}{$\begin{array}{c}\text { OTA } \\
\text { concentration } \\
(\mathrm{ppb})\end{array}$} & \multicolumn{2}{|c|}{24} & \multicolumn{2}{|c|}{48} & \multicolumn{2}{c|}{72} \\
\cline { 2 - 7 } & Hep-2 & Hfl-1 & Hep-2 & Hfl-1 & Hep-2 & Hfl-1 \\
\hline 40 & 96.79 & 87.76 & 98.29 & 84.21 & 98.88 & 97.94 \\
\hline 20 & 96.95 & 73.43 & 98.13 & 81.57 & 98.15 & 97.92 \\
\hline 10 & 60.23 & 68.95 & 71.31 & 75.00 & 97.83 & 96.74 \\
\hline 5 & 43.18 & 60.52 & 51.36 & 65.97 & 90.53 & 92.60 \\
\hline 2.5 & 36.18 & 46.05 & 38.54 & 50.14 & 88.30 & 82.54 \\
\hline 1.25 & 26.42 & 30.26 & 34.85 & 44.77 & 82.48 & 73.07 \\
\hline 0.63 & 20.31 & 20.39 & 29.16 & 44.71 & 82.33 & 71.89 \\
\hline 0.31 & 18.32 & 17.10 & 28.20 & 28.65 & 77.34 & 69.23 \\
\hline
\end{tabular}

Table.5 The cytotoxic effect of OTA (60ppb) extract produced by an A. ochraceus strain CBS 588.68 on Hep-2 and Hfl-1 cell lines at different incubation periods

\begin{tabular}{|c|c|c|c|c|c|c|}
\hline \multirow{2}{*}{$\begin{array}{c}\text { OTA } \\
\text { concentration } \\
(\mathrm{ppb})\end{array}$} & \multicolumn{9}{|c|}{24} & \multicolumn{2}{|c|}{48} & \multicolumn{2}{c|}{72} \\
\cline { 2 - 7 } & Hep-2 & Hfl-1 & Hep-2 & Hfl-1 & Hep-2 & Hfl-1 \\
\hline 60 & 96.79 & 74.34 & 98.29 & 92.00 & 98.88 & 98.81 \\
\hline 30 & 96.95 & 67.76 & 98.13 & 89.55 & 98.15 & 93.78 \\
\hline 15 & 60.23 & 57.89 & 71.31 & 77.05 & 97.83 & 83.13 \\
\hline 7.5 & 43.18 & 54.60 & 51.36 & 71.89 & 90.53 & 73.43 \\
\hline 3.75 & 36.18 & 33.55 & 38.54 & 58.57 & 88.3 & 69.85 \\
\hline 1.87 & 26.42 & 27.63 & 34.85 & 43.19 & 82.48 & 65.34 \\
\hline 0.94 & 20.31 & 15.13 & 29.16 & 41.42 & 82.33 & 62.38 \\
\hline 0.47 & 18.32 & 05.26 & 28.20 & 39.34 & 77.34 & 60.59 \\
\hline
\end{tabular}

Table.6 The cytotoxic effect of OTA $(50 \mathrm{ppb})$ extract produced by $P$. verrucosum strain IMI 285522 on Hep-2 and Hfl-1 cell lines at different incubation periods

\begin{tabular}{|c|c|c|c|c|c|c|}
\hline \multirow{2}{*}{$\begin{array}{c}\text { OTA } \\
\text { concentration } \\
(\mathrm{ppb})\end{array}$} & \multicolumn{2}{|c|}{24} & \multicolumn{2}{|c|}{48} & \multicolumn{2}{c|}{ Incubation time (hr) } \\
\cline { 2 - 7 } & Hep-2 & Hfl-1 & Hep-2 & Hfl-1 & Hep-2 & Hfl-1 \\
\hline 50 & 96.59 & 86.86 & 97.90 & 94.73 & 99.62 & 99.11 \\
\hline 25 & 50.00 & 81.04 & 70.35 & 87.50 & 98.50 & 97.63 \\
\hline 12.5 & 40.62 & 65.07 & 65.06 & 76.30 & 90.61 & 80.76 \\
\hline 6.25 & 23.72 & 46.71 & 48.95 & 58.28 & 87.55 & 63.28 \\
\hline 3.125 & 18.03 & 32.89 & 44.23 & 53.25 & 73.84 & 57.31 \\
\hline 1.56 & 10.79 & 23.02 & 36.13 & 47.46 & 66.54 & 50.88 \\
\hline 0.78 & 10.70 & 09.86 & 30.40 & 40.97 & 48.43 & 48.50 \\
\hline 0.39 & 6.81 & 04.60 & 29.40 & 30.60 & 44.41 & 38.04 \\
\hline
\end{tabular}


In the rat kidney, tumour induction is seen at a dose level $(70 \mu \mathrm{g} / \mathrm{kg}$ body weight (Boorman, 1989). Ochratoxin A is not mutagenic and only weak genotoxic effects have been observed in some mammalian cell systems (Bendele et al., 1985; Doop et al., 1999; Ehrlich et al., 2002; Follmann and Lucas, 2003; Zepnik et al., 2001). Experiments using radio- labeled OTA indicate that OTA does not form covalent DNA adducts in detectable concentration (Gautier et al., 2001; Gross-Steinmeyey et al., 2002; Mally et al., 2004). However OTA is only slowly eliminated in rats and tissuespecific retention may play an important role in OTA toxicity (Zepnik et al., 2003).

Ochratoxin A has been found in human blood samples, and it was found more frequently at high average concentration in blood samples obtained from people living in regions where a fatal human kidney disease occurs (Perkova-Bocharova et al., 1988). As cereals are widely used in animal feeds in many parts, OTA may come through animal products in human diet and absorbed from the gastrointestinal tract. Distribution in a number of species is via blood, mainly to the kidneys, lower concentrations being found in liver, muscle and fat. Transfer to milk has been demonstrated in rats, and humans, but little transferred to the milk of ruminants owing to metabolism of OTA by the rumen microflora (Creppy, 2002). The 4,5(dimethylthiazol-2-yl) and 2,5diphenyltetrazolium bromide (MTT) assay have been used by many authors for cytotoxicity screening and was established as accurate, rapid and reproducible for assaying the viability of various cell lines on exposure to mycotoxins (Hanelt et al., 1994; Widestrand et al, 2003). Other colorimetric assays including bromodeoxyuridine uptake (Eriksen et al., 2004; Widestrand et al, 1999), trypan blue exclusion assay (Robb et al., 1990) and lactate dehydrogenase (Widestrand et al, 1999) have been used, however, the MTT assay is the most widely employed among the other techniques.

Since crude toxin extracts were used for cytotocity assay, it is likely that the cytotoxic effects shown could have been caused by the toxin alone, the toxin in combination with other extracted compounds or even the latter. Although the solvent was evaporated and the extract reconstituted for the assay the role of other metabolites could not be ruled out. It is important that future work on the fungal isolates obtained in this study investigates the effect of purified enzyme extracts on different human cell lines. The significance of this study is that the secondary metabolites of the fungal isolates from Libya could have cytotoxic effects on mammalian cells.

\section{References}

Abarca, M.L., Accensi, F., Cano, J., Cabañes, F.J. 2004. Taxonomy and significance of black aspergilli. Ant van Leeuwen, 86: 33-49.

Battilani, P., Pietri, A., Bertuzzi, A.T., Languasco, L., Giorni, P., Kozakiewicz, Z. 2003. Occurrence of ochratoxin A-producing fungi in grapes grown in Italy. J. Food Prot., 66: 633-6.

Bendele, A.M., Neal, S.B., Oberly, T.J., Thompson, C.Z., Bewsey, B.J., Hill, L.E., Rexroat, M.A., Carlton, W.W., Probst, G.S. 1985. Evaluation of ochratoxin A for mutagenicity in a battery of bacterial and mammalian cell assays. Food Chem. Toxicol., 23: 911-918.

Betancur-Galvis, L.A., Saez, J., Granados, 
H., Salazar, A., Ossa, J.E. 1999. Antitumour and antiviral activity of Colombian medicinal plant extracts. Mem. Institute Oswaldo Cruz, 94: 531-535.

Boorman, G.A. 1989. Toxicology and Carcinogenesis Studies of Ochratoxin A in F344/N Rats, NTP Technical Report 358, NIH Publication No. 89: 2813.

Bondy, G.S., Armstrong, C.L. 1998. Cytotoxicity of nephrotoxic fungal toxins to kidney-derived LLC-PK1 and $\mathrm{OK}$ cell lines. J. Cell Biol. Toxicol., 14: 323-332.

Creepy, E.E., Kern, D., Steyn, P.S., Vleggaar, R., Roschenthaler, R., Dirheimer, G. 1983. Comparative study of the effect of ochratoxin A analogues on yeast aminoacyl-tRNA synthetatse and on the growth and protein synthesis of hepatoma cells. Toxicol. Lett., 19: 217-224.

Creppy, E., Edmond. 2002. Update of survey, regulation and toxic effects of mycotoxins in Europe. Toxicol. Lett., 172: 19-28.

Dalcero, A., Magnoli, C., Hallak, C., Chiacchiera, S.M., Palacio, G., Da Rocha Rosa, C.A. 2002. Detection of ochratoxin A in animal feeds and capacity to produce this mycotoxin by Aspergillus section Nigri in Argentina. Food Addit Contam., 19: 1065-72.

Dietrich, D.R., O'Brien, E., Stack, M.E., Heuuner, A.H. 2001. Species-and sex specific renal cytotoxicity of ochratoxin A and $\mathrm{B}$ in vitro. Experimmental and Toxicol. Pathol., 53: 215-225.

Dopp, E., Muller, J., Hahnel, C. and Schiffmann, D. 1999. Induction of genotoxic effects and modulation of the intracellular calcium level in Syrian hamster embryo (SHE) fibroblasts caused by ochratoxin A.
Food Chem. Toxicol., 7: 713-721.

Ehrlich, V., Darroudi, F., Uhl, M., Steinkellner, H., Gann, M., Majer, B. J., Eisenbauer, M. and knasmuller, S. 2002. Genotoxic effects of ochratoxin $\mathrm{A}$ in human-derived hepatoma (HepG2) cells. Food Chemistry and Toxicol., 40: 1085-1090.

Eriksen, G.S., Pettersson, H., Lundh, T 2004. Comparative cytotoxicity of deoxynivalenol, nivalenol, their acetylated derivatives and de-epoxy metabolites. Food Chemistry and Toxicol., 42: 619-624.

Finlay, W.J.J., Logan, N.A., Sutherland, A.D. 1999. Development of a semiautomated metabolic staining assay for Bacillus cereus emetic toxin. Appl. Environ., 56: 1811-1812.

Follmann, W., Lucas, S. 2003. Effects of the mycotoxin ochratoxin A in a bacterial and a mammalian in vitro mutagenicity test system. Arch. Toxicol., 77: 298-304.

Gautier, J., Richoz, J., Welti, D. H., MArkovic, J., Gremaud, E., Guengerich, F.P., Turesky, R.J. 2001. Metabolism of ochratoxin A: absence of formation of genotoxic derivatives by human and rat enzymes. Chem. Res. Toxicol., 14: 34-45.

Gekle, M., Schwerdt, G., Freudinger, R., Mildenberger, S., Wilflingseder, D., Pollack, V., Dander, M., Schramek, H. 2000. Ochratoxin A induces JNK activation and apoptosis in MDCK-C7 cells at nanomolar concentration. $J$. Pharmacol. Exp. Ther., 293: 837-844.

Gross-Steinmeyer, K., Weymann, J., Hege, H.G., Metzler, M. 2002. Metabolism and lack of DNA reactivity of the mycotoxin ochratoxin A in cultured rat and human primary hepatocytes. $J$. Agriculture and Food Chem., 50: 938945.

Gupta, M., Bandyopaddhyay, S., Paul, B. 
and Majumder, S.K. 1979. Hematological changes produced in mice by ochratoxin A. Toxicol., 14: 95-98.

Hanelt, M. Garies, M. and Kollarczik, B. (1994). Cytotoxicity of myctoxins evaluated by the MMT-cell culture assay. Mycopathologia, 128: (3) 167174.

Krogh, P., Gyrd-Hansen, N., Hald, B., Larsen, S., Nielsen, J.P., Smith, M., Ivanoff, C., Meisner, H. 1988. Renal enzyme activities inexperimental ochratoxin A induced porcine nephropathy: diagnostic potential of phosphoenolpyruvate carboxykinase and gamma glutamyl transpeptidase activity. J. Toxicol. Environ. Health, 23: $1-14$.

Luhe, A., Hildebrand, H., Bach, U., Dingerman, T., Ahr, H.J. 2003. A new approach to studying ochratoxin A (OTA)-induced nephrotoxicity: expression and profiling in vivo and in vitro employing cDNA microarrays. Toxicol. Sci., 37(2): 315-328.

Magnoli, C., Violante, M., Combina, M., Palacio, G., Dalcero, A. 2003. Mycoflora and ochratoxin-producing strains of Aspergillus section Nigri in wine grapes in Argentina. Lett. Appl. Microbiol., 37: 179-84.

Magnoli, C., Astoreca, A., Ponsone, L., Combina, M, Palacio, G, Da Rocha Rosa CA, et al 2004. Survey of mycoflora and ochratoxin A in dried vine fruits from Argentina markets. Lett Appl Microbiol 39: 326-31.

Magnoli C, Hallak C, Astoreca A, Ponsone L, Chiacchiera SM, Palacio G, et al. (2005). Surveillance of toxigenic fungi and ochratoxin $\mathrm{A}$ in feedstuffs from Cordoba province, Argentina. Vet Res Commun., 29:431-45.

Magnoli C, Hallak C, Astoreca A, Ponsone L, Chiacchiera S, Dalcero A (2006a).
Occurrence of ochratoxin A-producing fungi in commercialcorn kernels in Argentina. Mycopathologia, 161: 538.

Magnoli, C., Astoreca, A., Ponsone, M.L., Fernández-Juri, M.G., Barberi, C., Dalcero, A. 2006b. Ochratoxin A and Aspergillus section Nigri in peanutseeds at different months of storage in Córdoba, Argentina. J. Sci. Food Agric., 86: 2369-73.

Mally, A., Zepnik, H., Wanek, P., Eder, E., Dingley, K., Ihmels, H., Völkel, W. and Dekant, W. 2004. Ochratoxin A: Lack of formation of covalent DNA adducts. Chem. Res. Toxicol., 17: 234242.

Omar, R.F., Rahimtula, A.D., Bartsch, H. 1991. Role of cytochrome P450 in ochratoxin A stimulated lipid peroxidation. J. Biochemistry and Toxicol., 6: 203-209.

Perkova-Bocharova, T., Chernozemsky, I. N., Castegnaro, M. 1988. Ochratoxin $\mathrm{A}$ in human blood in relation to Balkan Endemic nephropathy and urinary system tumours in Bulgaria. Food Additives and Contaminants, 5: 299-301.

Pitout, M.J. 1986. The effect of ochratoxin A on glycogen storage in rat liver. Toxicol. Appl. Pharmacol., 13: 299309.

Pardo, E., Marín, S., Ramos, A.J., Sanchis, V. 2004. Occurrence of ochratoxigenicfungi and ochratoxin A in green coffee from different origins. Food Sci. Technol. Int., 10: 45-9.

Robb, J., Norval, M., Neil, W.A. 1990. The use of tissue culture for the detection of mycotoxins. Lett. Appl. Microbiol., 10: 161-165.

Rosa, C.A.R., Ribeiro, J.M.M., Fraga, M.J., Gatti, M., Cavaglieri, LR.,. Magnoli, C.E., et al. 2006. Mycoflora of poultry feeds and ochratoxin-producingability 
of isolated Aspergillus and Penicillium species. Vet. Microbiol., 113: 89-96.

Samson, R.A., Hokstra, E.S., Frisvad, J.C., Filteenborg, O. 2002. Methods for detection and isolation in food-born fungi. Introduction to food fungi 6th Ed. Centraalbureau voor Schimmelcultures, Baarn pp 76-77.

Samson, R.A., Houbraken, J.A.M.P., Kuijpers, A.F.A., Frank, J.M., Frisvad, J.C. 2004. New ochratoxin A or sclerotium producing species in Aspergillussection Nigri. Stud. Mycol., 50: 45-61.

Schaaf, G.J., Nijmeijer, S.M., Maas, R.F. M., Roestenberg, P., de Groene, E.M., Fink-Gremmels, J. 2002. The role of oxidative stress in the ochratoxin Amediated toxicity in proximal tubular cells. Biochim. Biophys. Acta., 1588: 149-158.
Widestrand, J., Lundh, T., Pettersson, H., Lindberg, J.F. 1999. Cytotoxicity of four trichothecense evaluated by three colorimetric Mycopathologia, 147: 149-155.

Widestrand, J., Lundh, T., Pettersson, H., Lindberg, J.F. 2003. A rapid and a sensitive screening assay for thrichothecense in cereal samples. Food Chem. Toxicol., 41: 1307-1313.

Zepnik, H., Pahler, A., Schauer, U. and Dekant, W. 2001. Ochratoxin A induced tumor formation: is there a role of reactive ochratoxin A metabolites? Toxicol. Sci., 9: 59-67.

Zepnik, H., Volkel, W. and Dekant, W. 2003. Toxicokinetics of the mycotoxin ochratoxin A in F 344 rats after oral administration. Toxicol. Appl. Pharmacol., 192: 36-44.

\section{How to cite this article:}

Jamal I. Elzwai, Mohamed A. Ahmed, Kofi A. Aidoo, Allan A. Candlish and Alyaa M. Homoud. 2016. Studies on Cytotoxic Effects of Ochratoxin A Extracts on Human Cell Lines (Hfl-1 And Hep-2). Int.J.Curr.Microbiol.App.Sci. 5(7): 61-70. doi: $\underline{\text { http://dx.doi.org/10.20546/ijcmas.2016.507.005 }}$ 